\title{
A New Record From East Malaysia: Sphaerolaimus macrocirculus (Nematoda)
}

\author{
NORLIANA MOHD ROSLI*¹, SHABDIN MOHD LONG ${ }^{2}$, CHENG-ANN CHEN ${ }^{3}$ \\ ${ }^{I}$ Department of Biology, Faculty of Science and Mathematics, Sultan Idris Education University, 35900 Tanjong \\ Malim, Perak; ${ }^{2}$ Department of Aquatic Science, Faculty of Resource Science and Technology, Universiti Malaysia \\ Sarawak, 94300 Kota Samarahan, Sarawak, Malaysia; ${ }^{3}$ Borneo Marine Research Institute, Universiti Malaysia \\ Sabah, Jalan UMS, 88400 Kota Kinabalu, Sabah, Malaysia.
}

\begin{abstract}
A new record of Sphaerolaimus macrocirculus (Filipjev 1918) in East Malaysian coastal water was described. The species was isolated from the muddy area of Muara Tebas, Sarawak, Malaysia. A total of 47 species of Sphaerolaimus have been reported worldwide. Samples of Sphaerolaimus macrocirculus were previously recorded in the sublittoral mud area of temperate country. S. macrocirculus possesses a stout body (1.1 - 1.6 $\mathrm{mm}$; De Man ratios: a (body length/body width $=16.8-27.5$; b (body length/oesophagus length) $=2.3-4.3$; $\mathrm{c}$ (body length/tail length) $=5.6-8.6)$. The circular amphid is very clear and situated at the base of the cephalic capsule. In male, the amphid ranged from $11.3-14.3 \mu \mathrm{m}$ in diameter (mean = $12.7 \pm 1.3$ ) and 0.4 c.d. (corresponding diameter). In female, the amphid ranged from $7.2-9.4 \mu \mathrm{m}$ in diameter (mean $7.8 \pm 0.9$ ) and 0.2 c.d. The species is characterised by the presence of eight groups of subcephalic setae at the head region and three longer terminal setae.
\end{abstract}

Keywords: East Malaysia, Sphaerolaimus, Nematoda

\section{INTRODUCTION}

Sarawak is the largest of Malaysia's thirteen states. The state has a long coastline stretches over $800 \mathrm{~km}$ along the northwest coast of Borneo.

However, research on free-living nematodes is still scarce not only in Sarawak but Malaysia. Recently, only a few researches had been conducted on free-living marine nematodes in Malaysia (Shabdin \& Othman 2005; Chen \& Shabdin 2009; Chen et al. 2012). Before that, the studies in Malaysia only covered the ecology and diversity of meiobenthos (Sasekumar 1994; Somerfield et al. 1998; Shabdin \& Othman 2005; Sakri et al. 2006; Shabdin 2006). Preliminary studies in Sarawak related to marine nematodes only covered the density of higher meiofauna taxa (Bejie et al. 1999; Tengku Balkis \& Shabdin 2001). Chen et al. (2012) lead the study of marine nematode in Sarawak. Free-living nematodes play an important role in marine ecosystem providing the food source for macro-consumers (Chinnadurai \& Fernando 2007) and also as pollution indicator. The

*Corresponding author: norliana.m@fsmt.upsi.edu.my present study has been conducted to assess the species that presence in Muara Tebas, Sarawak, Malaysia together with their taxonomic structure. Muara Tebas was chosen as the sampling site due to its geographical location at Sarawak River mouth where the freshwater meet the saline that contains unique community structure.

One species, Sphaerolaimus macrocirculus (Filipjev 1918) had been documented in the study area. This species is a new record of free-living marine nematodes in East Malaysian coastal waters. So far, about 47 species in this genus have been reported worldwide. Sphaerolaimus penicillus was recorded in Sabah (Shabdin \& Othman 2008) and none from Sarawak. Most of the Sphaerolaimus spp. are recorded in temperate country. Genus Sphaerolaimus was described by Bastian (1865) with characters such as having buccal cavity surrounded by solid, heavily sclerotized buccal capsule (Warwick et al. 1998). The inner lining of oesophagus strongly cuticularised and groups of subcephalic setae can be observed clearly. Sphaerolaimus macrocirculus is characterized by having a large buccal cavity, barrel shaped 
and heavily cuticularised. They have faint transverse striations of cuticle which are not always visible. The circular amphid is situated at the base of cephalic capsule. Three longer terminal setae are the characterization in this species that differ from the others. $S$. macrocirculus was previously recorded in the sublittoral mud area. Many species from genus Sphaerolaimus are known to be carnivores, feeding particularly on other nematodes (Filipjev 1918).

\section{MATERIALS \& METHODS}

A transparent corer of four $\mathrm{cm}$ diameter was used to collect the samples. Samples for nematode study were preserved in 5\% formalin in the field and were brought back to the laboratory for further analysis and identification.

Nematodes were extracted using a $45 \mu \mathrm{m}$ sieve. They were rinsed with tap water to remove the formalin and the residues that retained on the sieve were transferred to a Petri dish and sorted under stereomicroscope. Then, they were mounted on slide using standard method (Platt \& Warwick 1983).
The nematode morphology and characteristic were observed and drawn using compound microscope equipped with Camera Lucida (Model Zeiss MC 80 DX). The identifications were based on several keys of identification (Platt \& Warwick 1983, 1988; Warwick et al. 1998). The following abbreviations were used: a, b, c: de Man's ratios; a.b.d.: anal/cloacal body diameter; c.d.: corresponding diameter; spic arc: length of spicule along the arc; $\mathrm{V} \%$ : position of vulva as percentage of total body length from anterior.

\section{RESULTS}

\section{Type specimen}

Four males and nine females were examined. Holotype: male (SML0188). Paratypes: three males (SML0199, 0201, 0214). Allotype: female (SML0131). Paratypes: eight females (SML0166, 0185, 0186, 0189, 0191, 0215, 0216, 0219).

Type locality and habitat: Intertidal zones, Muara Tebas, Sarawak, Malaysia; located near the river mouth of Sarawak River. Muddy area dominated with Avicennia marina.

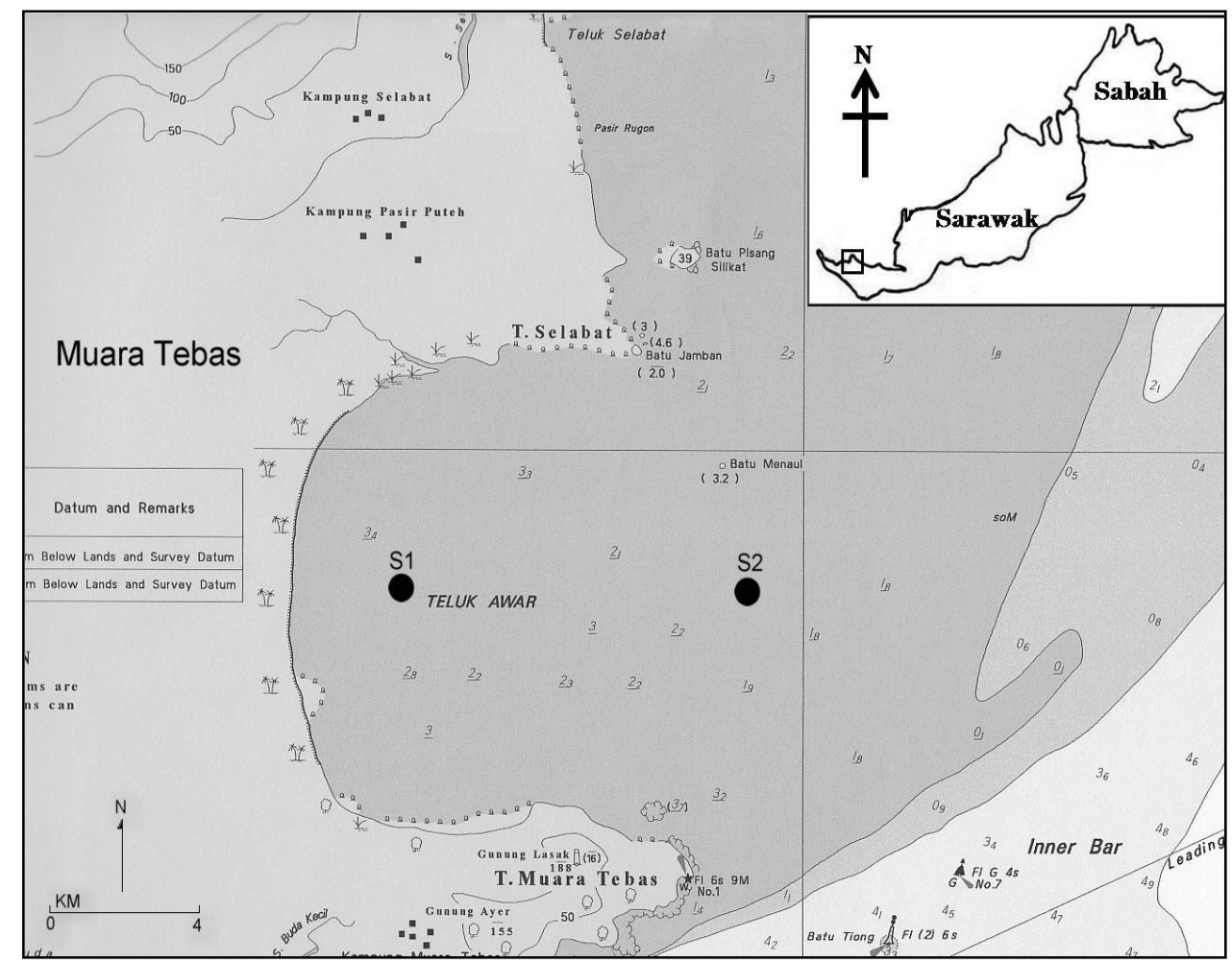

Figure 1. Site location (Muara Tebas, Sarawak). 


\section{Systematic}

Class Adenophorea

\author{
Subclass Chromadoria \\ Order Monhysterida \\ Suborder Monhysterina \\ Superfamily Monhysteroidea \\ Family Sphaerolaimidae \\ Subfamily Sphaerolaiminae \\ Genus Sphaerolaimus
}

Species macrocirculus

\section{Measurement}

Holotype: $\mathrm{L}=1238.6 \mu \mathrm{m}, \mathrm{a}=23.9, \mathrm{~b}=4.3$, c $=7.4($ Table 1$)$

Males ( $\mathrm{n}=4$, including holotype): $\mathrm{L}=(1.1-$ $1.2 \mathrm{~mm})$

Allotype: $\mathrm{L}=1532 \mu \mathrm{m}, \mathrm{a}=27.5, \mathrm{~b}=3.9, \mathrm{c}=$ $8.3, \mathrm{~V}=62.2 \%$ (Table 2)

Females $(\mathrm{n}=9$, including allotype $): \mathrm{L}=(1.2-$ 1.6) $\mu \mathrm{m}, \mathrm{V}=(62-77) \%$

\section{Description}

MALE (Holotype SML0188: range and/or average \pm s.d. in parentheses): Body stout, 1.3 $\mathrm{mm}$ long $(1.1-1.2,1.2 \pm 0.05) \mathrm{mm}$ (Figure 2D). Maximum diameter $51.8 \mu \mathrm{m}(51.8-66.9$, $57.5 \pm 6.5) \mu \mathrm{m}, \mathrm{a}=23.9, \mathrm{~b}=4.3, \mathrm{c}=7.4(\mathrm{a}=$ $17.3-23.9,21.5 \pm 2.9 ; b=3.9-4.3,4.1 \pm$ $0.2 ; c=6.9-7.6,7.2 \pm 0.4)$. Cuticle with faint and fine transverse striations, which mostly visible in all specimens. Somatic setae were short and scattered along the body.

Head diameter $26.4 \mu \mathrm{m}(23.9-28.2,26.0 \pm$ 1.8) (Figure 2A) with six small labial papillae. Cephalic setae short $(2.8 \mu \mathrm{m})$. Eight groups of subcephalic setae situated between amphids and cephalic setae with three to four setae in each groups (Figure 2A). Subcephalic setae long with $14.9 \mu \mathrm{m}(14.1-16.9,15.3 \pm 1.2)$. Cervical setae length: long $(7.2-13.8) \mu \mathrm{m}$ and short $(2.8-5.5) \mu \mathrm{m}$, arranged longitudinally in a row (eight or nine) from head region to the mid part of oesophagus. Clearly visible amphids situated at the base of the cephalic capsule. Amphid located at $25.3 \mu \mathrm{m}$ (22.5 $25.4,24.3 \pm 1.3) \mu \mathrm{m}$ from anterior body end.

Table 1. Morphometrics of Sphaerolaimus macrocirculus (male).

\begin{tabular}{ccccc}
\hline \multirow{2}{*}{ Characters $(\mu \mathrm{m})$} & Holotype & \multicolumn{3}{c}{ Paratype } \\
\cline { 2 - 5 } & SML0188 & SML0199 & SML0201 & SML0214 \\
\hline Total body length & 1238.6 & 1158.8 & 1229.3 & 1270.2 \\
Head diameter & 26.4 & 28.2 & 25.4 & 23.9 \\
Amphids diameter & 14.3 & 12.7 & 11.3 & 12.7 \\
Amphids c.d. & 0.5 & 0.4 & 0.4 & 0.5 \\
Amphids ant. & 25.3 & 25.4 & 23.9 & 22.5 \\
Oesophagus length & 289.7 & 284.1 & 295.3 & 328.7 \\
Oesophagus c.d. & 31.4 & 36.6 & 33.8 & 31.0 \\
Max. diameter & 51.8 & 66.9 & 55.7 & 55.7 \\
Spicule arc & 82.6 & 59.2 & 59.2 & 53.5 \\
Tail length & 167.1 & 167.1 & 178.3 & 167.1 \\
Cloacal diameter & 39.0 & 44.6 & 44.6 & 44.6 \\
a.b.d & 4.3 & 3.8 & 4.0 & 3.8 \\
a & 23.9 & 17.3 & 22.1 & 22.8 \\
b & 4.3 & 4.1 & 4.2 & 3.9 \\
c & 7.4 & 6.9 & 6.9 & 7.6 \\
\hline
\end{tabular}

Notes: c.d.: corresponding diameter; a.b.d.: anal/cloacal body diameter; a, b, c: de Man's ratios; Spicule arc.: Length of spicule measured on arc; Amphids ant.: Amphids from anterior; Max. diameter: Maximum body diameter. All measurements in $\mu \mathrm{m}$, except for de Man's ratios $(\mathrm{a}, \mathrm{b}, \mathrm{c})$, c.d. and a.b.d. 
Table 2. Morphometrics of Sphaerolaimus macrocirculus (female).

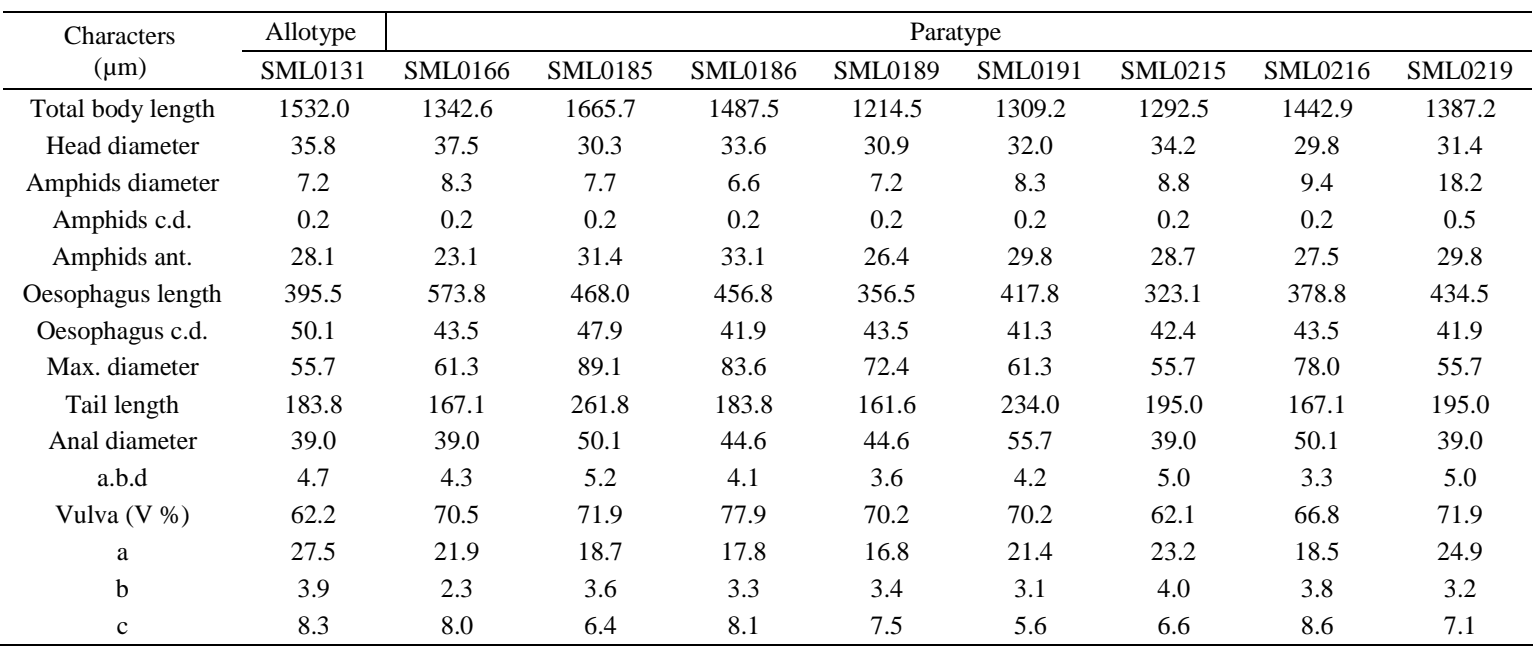

Notes: c.d.: corresponding diameter; a.b.d.: anal/cloacal body diameter; a, b, c: de Man's ratios; Amphids ant.: Amphids from anterior; Max. diameter: Maximum body diameter; V \%: position of vulva as percentage of total body length from anterior. All measurements in $\mu \mathrm{m}$, except for de Man's ratios (a, b, c), c.d. and a.b.d.

Amphid circular, $14.3 \mu \mathrm{m}(11.3$ - 14.3, 12.7 $\pm 1.3) \mu \mathrm{m}$ in the diameter; 0.5 c.d. $(0.4-0.5)$ c.d. Barrel-shaped buccal cavity; not completely surrounded by oesophageal tissue. Buccal cavity with alternating heavily and weakly punctuated areas. Two sclerotized rings at the posterior end of buccal cavity. Oesophagus widens posteriorly, but has no distinct bulb and strongly sclerotized. Oesophagus length 0.28 $\mathrm{mm}(0.28-0.32,0.29 \pm 0.02) \mathrm{mm}$. Cardia and nerve ring were not visible.

Single testes were noted. Spicule was long and slender from distal to proximal. Length of spicule form the arc was $82.6 \mu \mathrm{m}(53.5-$ $82.6,63.6 \pm 13.0) \mu \mathrm{m}$ (Figure 2F). The gubernaculum were small. No precloacal supplements detected. Short caudal setae (2.2 - 3.3) $\mu \mathrm{m}$ scattered randomly at the end of tail. Two caudal gland noted in male. Tail 4.3 a.b.d. $(3.8-4.3,3.9 \pm 0.3)$ a.b.d. The anterior tail was two thirds conical and the remainder is cylindrical. Tail length from anus, $0.16 \mathrm{~mm}$ $(0.16-0.17,0.16 \pm 0.05) \mathrm{mm}$. Three long terminal setae $(16-20.4) \mu \mathrm{m}$.

FEMALE (Allotype SML0131: range in parentheses). Similar to males in most features. Females body, $1.5 \mathrm{~mm}$ (1.2-1.6, 1.4 $\pm 0.1) \mathrm{mm}$ longer than in males $(1.1-1.2)$ $\mathrm{mm}$ (Figure 2C). Maximum body diameter 55.7 $\mu \mathrm{m}(55.7-89.1,68.1 \pm 13.0) \mu \mathrm{m}, \mathrm{a}=27.5, \mathrm{~b}=$ $3.9, \mathrm{c}=8.3(\mathrm{a}=16.8-27.5,21.2 \pm 3.6 ; \mathrm{b}=2.3$ $-4.0,3.4 \pm 0.5 ; \mathrm{c}=5.6-8.6,7.4 \pm 1.0$ ).

Head diameter $35.8 \mu \mathrm{m}(29.8-37.5,32.8 \pm$ 2.6) (Figure 2B). Cephalic setae short, $3.9 \mu \mathrm{m}$ (3.3 - 3.9, 3.2 \pm 1.2$) \mu \mathrm{m}$. Subcephalic setae long $19.3 \mu \mathrm{m}(17.6-27.0,19.8 \pm 3.1)$, situated in eight group. Amphids located at a similar position in males, at the base of cephalic capsule, but smaller in diameter, $7.2 \mu \mathrm{m}$ (7.2 9.4, $7.8 \pm 0.9) \mu \mathrm{m}$. Amphid located at $28.1 \mu \mathrm{m}$ $(23.1-33.1,28.7 \pm 2.9) \mu \mathrm{m}$ from anterior body end. Two sclerotized rings clearly noted at the posterior end buccal cavity of female. Oesophagus length in female longer than male, $0.39 \mathrm{~mm}(0.32-0.57,0.42 \pm 0.07) \mathrm{mm}$.

Females are monodelphic, with single anterior outstretched ovary, clearly can be seen in matured females. Ovary located right from the anterior intestine extended posteriorly to the vulva. Vulva located at $62 \%(62-77,69.3 \pm$ $5.0) \%$ of body length. Vulva short, slit-like. One egg observed in uterus, oval shape. Caudal gland obscure in female. Caudal setae were short $(5.5-7.2) \mu \mathrm{m}$ but a little bit longer than male $(2.2-3.3) \mu \mathrm{m}$. Tail length from anus 0.18 $\mathrm{mm}(0.16-0.26,0.19 \pm 0.03)$ (Figure 2E). 


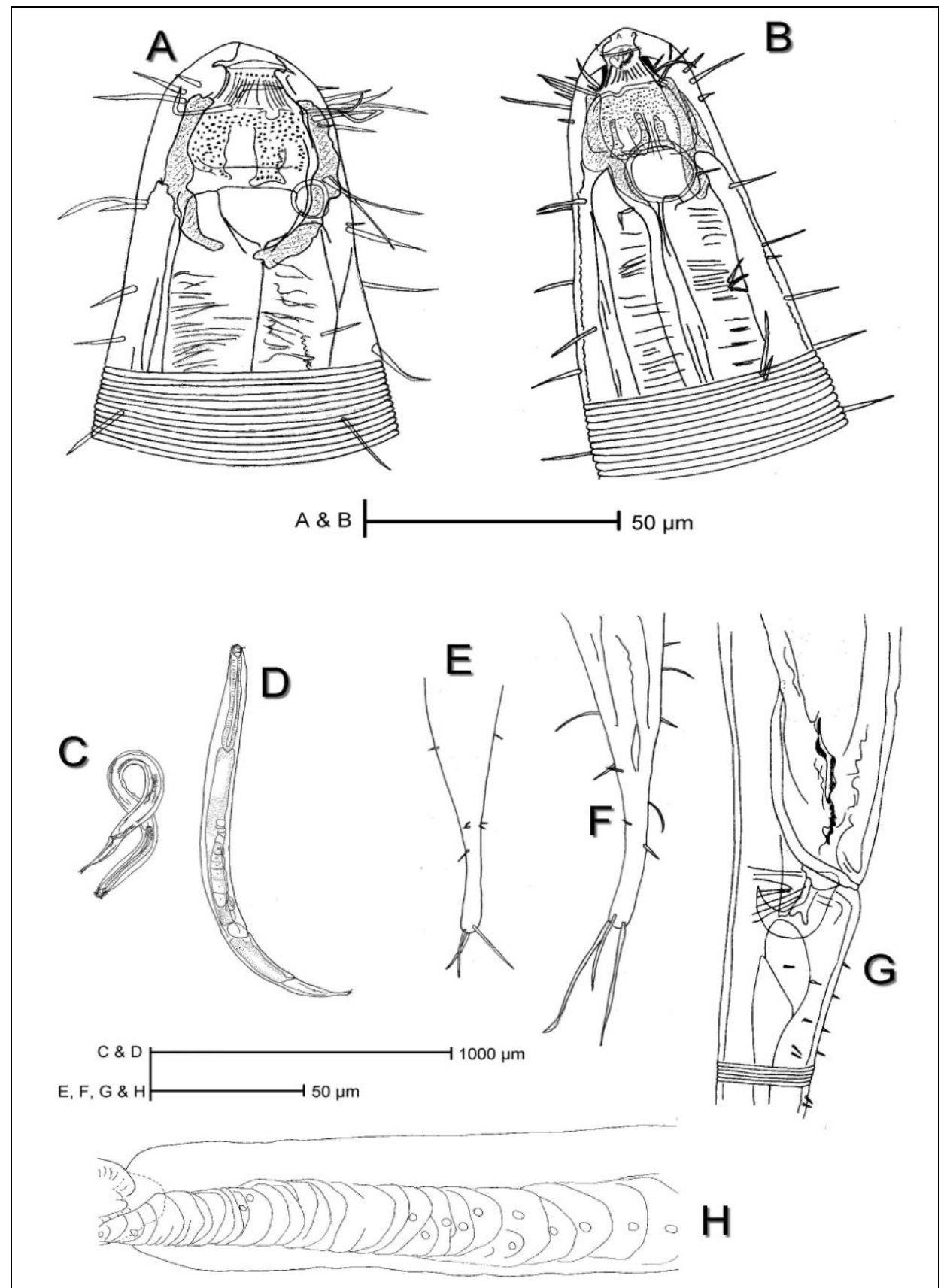

Figure 2. Sphaerolaimus macrocirculus Filipjev, 1918. Male (B, C, E, G, holotype SML0188): B. Head. C. Entire body. E. Tail. G. Cloacal region. Female (A, D, F, H, SML0131): A. Head. D. Entire body. F. Tail. H. Anterior, single ovary.

\section{Distribution}

Malaysia: Muara Tebas, Sarawak, Malaysia.

Global: Adriatic Sea (Travisi \& Vidakovic 1997), Black Sea and Mediterranean Sea (Gerlach \& Riemann 1973), European waters (De Smet et al. 2001), North Atlantic (Warwick et al. 1998), United Kingdom Exclusive Economic Zone (MEDIN 2011).

\section{DISCUSSION}

S. macrocirculus was first described by Filipjev, 1918. The present specimens examined conform well to the earlier description by Warwick et al. (1998) except for the smaller body size. The total length of the body in present specimen is shorter $(1.2-$ $1.6 \mathrm{~mm}$ ) compared to the previous studies (1.9 $-2.2 \mathrm{~mm}$ ) with smaller ratios. But, it is still 
within the range that supported by the original population of Filipjev (1918) and Schuurmans Stekhoven (1950 in Deprez 2005) (1.8 mm; 1.2 - $2.1 \mathrm{~mm}$ respectively) compared to Warwick et al. (1998). Besides that, cephalic setae and amphids are also shorter and smaller compared to Warwick et al.'s (1998) population.

However, slight differences occurred in male specimen where the length of spicule differs markedly (160-167 $\mu \mathrm{m}$ in previous population) compared to $82.6 \mu \mathrm{m}$ in the present. The precloacal supplements also were not visible in the present specimen, which they are visible in Warwick et al.'s samples (1998), by having seven precloacal supplements that contains raised pores (but they were not visible in all specimens).

These probably due to the differences in maturity of specimen since the precloacal supplements also absent in some of Filipjev's population. According to Gaugler \& Bilgrami (2004), there is distinct adult stage for nematodes, separated adult from juvenile by a moult, where fully formed gonads and copulatory apparatus are only found in the adults (Warwick et al. 1998).

Vulva in female is located at $62 \%$ (with range $62-77 \%$ ) of body length, differ with Warwick, Platt \& Somerfield's population which at $75 \%$ of body length. Schuurmans Stekhoven (1950 in Deprez 2005) also discovered the vulva of female specimen at $70 \%$ body length which also differs with previous finding.

Little is known about variations in body-size which might occur from place to place (Warwick et al. 1998). Ansari et al. (2012), recorded several species found in tropical region have smaller size than species that were found in temperate region.

The locality of geographical areas can play a significant role in the variety of individual of nematodes species. These differences can also be regarded as individual variation and cannot alone be justified as two different species (Vitiello 1970 in Deprez 2005).

\section{GENERAL CONCLUSIONS}

In conclusion, this specimen is morphologically resembles $S$. macrocirculus except for the smaller body size. These differences (variations of the body size of $S$. macrocirculus) potentially contributed either by the differences in geographical locations (temperate region and tropical region) or the maturity stage.

\section{ACKNOWLEDGEMENTS}

We would like to thank Universiti Malaysia Sarawak for providing the facilities to conduct the work and also the administrative and logistic support. Besides that, we would also like to thank Mr. Richard Toh for the help during the field sampling. Finally we would like to thank Ministry of Higher Education for supporting this project through FRGS/07(03)/786/2010(67).

\section{REFERENCES}

Ansari, K.G.M.T., Lyla, P.S., \& Ajmal Khan, S. (2012). New records of free-living marine nematodes (Nematoda: Enoplida) from Indian waters. Journal of the Marine Biological Association of India, 54(2): 5-11.

Bejie, N., Lau, S., \& Shabdin, M.L. (1999). Preliminary survey of intertidal meiofauna distribution in sediment at Kuching Bay, Sarawak. Malaysian Science and Technology Congress, 1999, Environmental and Renewable Resources, Kuching, Sarawak.

Chen, C.A. \& Shabdin, M.L. (2009). Horizontal distribution study of sandy nematodes from Muara Tebas, Sarawak, Malaysia. In L. Mohd. Talib, M. Che Abd. Rahim, U. Gires, O. Mohamed Rozali, M. Muzzneena Ahmad, A. Norhayati, O. Ramlan, Y. Shahruddin Hj \& L. Tukimat. Proceeding of International Conference of Marine Ecosystem 2009 ( $2^{\text {nd }}$ Volume $) 26$ 28 May 2009, Awana Porto Malai, Langkawi, Malaysia. EKOMAR, Universiti Kebangsaan Malaysia.

Chen, C.A. Shabdin, M.L., \& Norliana, M.R. (2012). Spatial distribution of tropical estuarine nematode communities in Sarawak, Malaysia (Borneo). The Raffles Bulletin of Zoology, 60(1): 173-181. 
Chinnadurai, G. \& Fernando, O.J. (2007). Meiofauna of mangroves of the southeast coast of India with special reference to the free-living marine nematodes assemblage. Estuarine Coastal and Shelf Science, 72: 329-336.

De Smet, G., Vincx, M., Vanreusel, A., Vanhove, S., Vanaverbeke, J., \& Steyaert, M. (2001). Nematoda - free living, in: Costello, M.J. et al. (Ed.) (2001). European register of marine species: a check-list of the marine species in Europe and a bibliography of guides to their identification. Collection Patrimoines Naturels, 50: 161-174.

Deprez, T. \& all 2005. NeMys. World Wide Web electronic publication. www.nemys.ugent.be, version (1/2013).

Filipjev, I.N. (1918). Free-living nematodes of the vicinities of Sevastopol. Issues 1 and 2. Reports of special zoological laboratory and Sevastopol biological station of Russian Academy of Sciences, ser. II, 4, 1-350. (English translation by M. Raven, 19681970. Israel Program for Scientific Translations, Jerusalem.)

Gaugler, R. \& Bilgrami, A.L. (Eds). (2004). Nematode Behavior. London, UK: CABI Publishing. p 423.

Gerlach, S.A. \& Riemann, F. (1973). The Bremerhaven Checklist of Aquatic Nematodes. Veröff. Inst. Meeresforsch. Bremerh. Suppl. 4, Heft 1.

MEDIN. (2011). UK checklist of marine species derived from the applications Marine Recorder and UNICORN, version 1.0 .

Platt, H.M. \& Warwick, R.M. (1983). Freeliving marine nematodes, part 1. British Enoplids. Cambridge: Cambridge University Press. p 307.

Platt, H.M. \& Warwick, R.M. (1988). Freeliving marine nematodes, part II. British Chromadorids. W. Backhuys Publishing, Leiden. p 501.
Sakri, I., Wan Mohd Rauhan, W.H., Zaleha, K., Zuliatini, M.J., Mohamad Zaidi, Z., \& Sukree, H. (2006). Seasonal abundance of benthic communities in coral areas of Karah Island, Terengganu, Malaysia. Turkish Journal of Fisheries and Aquatic Sciences, 6: 129-136.

Sasekumar, A. (1994). Meiofauna of a mangrove shore on the west coast of Peninsular Malaysia. Raffles Bulletin Zoology, 42: 901-915.

Shabdin, M.L. \& Othman, B.H.R. (2005). Seasonal variations of marine nematode assemblages in Sabah, Malaysia. Philippines Scientific, 42: 40-66.

Shabdin, M.L. \& Othman, B.H.R. (2008). Horizontal distribution of intertidal nematode from Sabah, Malaysia. Journal of Tropical Biology and Conservation, 4(1): 39-53.

Shabdin, M.L. (2006). Marine and estuarine meiofauna of Sarawak, Malaysia - a review. Sarawak Museum Journal LXII(83): 201222.

Somerfield, P.J., Gee, J.M., \& Aryuthaka, C. (1998). Meiofaunal communities in a Malaysian mangrove forest. Journal of Marine Biological Association of United Kingdom, 78: 717-732.

Tengku Balkis, T.S. \& Shabdin, M.L. (2001). The abundance, composition and density of meiofauna at Teluk Kuching, Sarawak. Regional Conference on Natural Resources and Environmental Management, Kuching Sarawak

Travisi, A. \& Vidakovic, J. (1997) Nematofauna in the Adriatic Sea: review and check-list of free-living nematode species. Helgoländer Meerseunters, 51: 503-519.

Warwick, R.M., Platt, H.M., \& Somerfield, P.J. (1998). Free-living nematodes (Part III) Monhysterids. In R.S.K. Barnes, \& J.H. Crothers (Eds.), Synopsis of British Fauna, No. 53. (p.296). Shewsbury: Field Studies Council. 